\title{
DIFFERENCES IN FOOD CONSUMPTION IN REGIONS OF POLAND THAT HAD BEEN PREVIOUSLY UNDER AUSTRIAN, PRUSSIAN AND RUSSIAN ANNEXATIONS
}

\author{
Anna Ukleja ${ }^{1}$, Dorota Szostak-Węierek ${ }^{1}$,Anna Waśkiewicz², Anita Aranowska², Wojciech Drygas ${ }^{2}$ \\ ${ }^{1}$ Department of Clinical Dietetics, Faculty of Health Sciences, Medical University of Warsaw, \\ Erazma Ciołka street 27, 01-445 Warsaw, Poland \\ ${ }^{2}$ Department of Epidemiology, Prevention of Cardiovascular Diseases and Health Promotion, Institute of \\ Cardiology, Niemodlińska street 33, 04-635 Warsaw, Poland
}

\begin{abstract}
Background. It seems that one of the factors affecting the way of nutrition in Poland was the dietary habits of countries that in the late 18th century made partitions, ie. Russia, Prussia and Austria. Therefore, nutrition models in the areas of individual partitions have undergone significant changes.

Objective. The aim of the study was to check whether after 85 years after regaining independence there were still differences in the way of feeding indigenous inhabitants of areas previously under Austrian, Prussian and Russian annexation.

Material and methods. The data collected during the WOBASZ survey carried out in the years 2003-2005 were used for the analysis.

Results. The greatest differences in the way of feeding were found in the area that was previously under the rule of Prussia. The nutrition model was still largely reminiscent of typical German cuisine. There was a large consumption of sausages and spreads, and small vegetables and fruit. Nutrition models in other areas were less characteristic.

Conclusions. The way of feeding indigenous people living in areas that were once partitions of Poland is still diverse and similar to the cuisine of the occupying country.
\end{abstract}

Key words: food consumption, Polish population, annexations, dietary habits

\section{STRESZCZENIE}

Wprowadzenie. Wydaje się, że jednym z czynników oddziałujących na sposób żywienia w Polsce były zwyczaje żywieniowe krajów, które w końcu XVIII wieku dokonały rozbiorów, tj. Rosji, Prus i Austrii. Dlatego modele żywienia na obszarach poszczególnych zaborów uległy istotnym zmianom.

Cel. Celem badania było sprawdzenie czy po 85 latach po odzyskaniu niepodległości nadal istniały różnice w sposobie żywienia rdzennych mieszkańców obszarów będących wcześniej pod zaborem austriackim, pruskim oraz rosyjskim.

Materiał i metody. Do przeprowadzonej analizy wykorzystano dane zebrane w toku badania WOBASZ przeprowadzonego w latach 2003-2005.

Wyniki. Największe odrębności w sposobie żywienia stwierdzono na obszarze będącym wcześniej pod panowaniem Prus. Model żywienia nadal w dużej mierze przypominał typową kuchnię niemiecką. Duże było spożycie kiełbas i tłuszczów do smarowania pieczywa, a małe warzyw i owoców. Modele żywienia na pozostałych obszarach były mniej charakterystyczne. Wnioski. Sposób żywienia ludności tubylczej mieszkającej na terenach, które kiedyś stanowiły zabory polskie, jest wciąż zróżnicowany i podobny do kuchni okupującego kraju.

Słowa kluczowe: spożycie żywności, populacja polska, zwyczaje żywieniowe

\section{INTRODUCTION}

Polish cuisine is not only a specific, traditional way of nutrition, but also an element of culture, which was shaped by various influences and inseparable from the history of Poland. On its development, in addition to climate and customs related to religion, the contacts with other cultures had a significant impact. In

Corresponding author: Anna Ukleja, Medical University of Warsaw, Faculty of Health Sciences, Department of Clinical Dietetics, Erazma Ciołka street 27, 01-445 Warsaw, Poland, phone: +48 660 683084, e-mail: anna.ukleja@wum.edu.pl

(C) Copyright by the National Institute of Public Health - National Institute of Hygiene 
varying degrees and at different times, French, Italian, German, Russian (Ruthenian), Austrian or Jewish influences can be observed [11]. Nevertheless, it can not be unequivocally stated that every few decades in Poland, new feeding patterns characteristic of other societies that completely displaced the previous ones came in. The character of Polish cuisine, passed down from generation to generation, was formed in the nineteenth century, and its final shape was influenced by the period of partitions, which together with the influx of foreign people brought new models of nutrition determined by social, economic and cultural conditions of the partitioning country. There is no doubt that the influence of the invaders significantly shaped the way Poles are fed in various regions of Poland [14, 17, 20, 28].

The aim of the conducted research was to check whether after 85 years since Poland regained independence and reunification of the country there were still differences in the way of feeding indigenous people who were previously under Austrian, Prussian and Russian annexation.

\section{MATERIAL AND METHODS}

The analysis uses data collected as part of the Multicultural National Population Health Survey (Wieloośrodkowe Ogólnopolskie Badanie Stanu Zdrowia Ludności -WOBASZ) conducted in adult Poles aged 20-74 in 2003-2005 by the Institute of Cardiology and five other scientific centers in the country. The detailed rules for conducting the WOBASZ survey, including the drawing of municipalities in individual voivodships and participants, are described in another publication [26].

Among the municipalities selected in the WOBASZ survey, those that were located in areas that before the Partitions were not part of the Kingdom of Poland and those where significant population migrations were recorded after the Second World War were excluded [8]. In addition, large cities and industrial centers were excluded. In this way, areas that can be assumed to be predominantly inhabited by the indigenous population are selected for the analysis described.

Selected communes were divided into three groups: previously under Austrian, Prussian and Russian annexation. The area of the former Austrian partition covered by the study was over 69,000 ha, the Prussian partition over 115,000 ha, and the Russian partition over 375,000 ha (Table I). 9 municipalities (4 small, 4 medium and 1 large) were selected from the former Austrian partition, 7 municipalities (3 small, 3 medium and 1 large) were selected from the Prussian partition and 25 municipalities were selected from the Russian partition (11 small, 10 medium and 4 big). In total, 41 municipalities were covered by the study. Their distribution on the map of Poland is presented in Figure 1. Taking into account the administrative status of the municipality, 5 Austrian rural municipalities, 3 urban-rural municipalities and 1 urban municipality were included in the Austrian partition, 3 rural municipality, 3 urban-rural and 1 urban were included in the Prussian partition, while in the Russian partition, 11 rural municipalities, 11 urban-rural municipalities and 3 urban municipalities (Table 2).

The analysis used the results of the nutrition assessment, which was carried out in the WOBASZ study participants. The method of nutrition was assessed using a 24-hour nutritional interview using the questionnaire method. Survey questionnaires were used from 41 communes collected from 605 persons $(282(46.61 \%)$ males and $323(53.39 \%)$ females) living in the area previously under Austrian partition, in 555 people (264 (47.57\%) men and 291 $(52.43 \%)$ women) living in an area previously under Prussian partition and in 1794 persons (839 (46.77\%) males and 955 (53.23\%) females) living in an area previously under Russian partition - Table 2 [16]. In total, the study covered 2954 people.

\section{Statistical analyzes}

The obtained results were subjected to statistical analysis using Statistical Analysis System (SAS), version 9.2. To describe the collected continuous variable results, the methods of descriptive statistics were used: means and standard deviations, and for the categorized variables, the frequency of occurrence of individual values.

In order to assess the diversity of the consumption of products in areas that were previously under different partitions and between different partitions, the Kruskal-Wallis test was used.

\section{RESULTS}

The average age of the surveyed men from the area of individual annexations was: 45.6 years (Austrian partition), 45.8 years (Prussian partition) and 46.2 years (Russian partition). Respectively for women: 44.0, 44.5 and 45.1 years. Differences in the average age were not statistically significant. The distribution in individual age groups is presented in Table 2. 
Table 1 . The distribution and features of the communes covered by the study

\begin{tabular}{|c|c|c|c|c|c|c|}
\hline No & Municipality & Voivodship & County & $\begin{array}{c}\text { Population } \\
\text { (2013) }\end{array}$ & Area [ha] & $\begin{array}{c}\text { Type of } \\
\text { municipality }\end{array}$ \\
\hline \multicolumn{4}{|c|}{ Austrian partition } & 182473 & 69567 & \\
\hline 1 & Dobczyce & Lesser Poland & myślenicki & 15114 & 6639 & urban-rural \\
\hline 2 & Grodzisko Dolne & podkarpackie & leżajski & 8094 & 7857 & rural \\
\hline 3 & Jasienica Rosielna & podkarpackie & brzozowski & 7722 & 5706 & rural \\
\hline 4 & Jedlicze & podkarpackie & krośnieński & 15476 & 5857 & urban-rural \\
\hline 5 & Lipnica Wielka & Lesser Poland & nowotarski & 5944 & 6736 & rural \\
\hline 6 & Nowy Sącz & podkarpackie & nowosądecki & 83943 & 5758 & urban \\
\hline 7 & Rymanów & podkarpackie & krośnieński & 15763 & 16663 & urban-rural \\
\hline 8 & Trzciana & Lesser Poland & bocheński & 5373 & 4409 & rural \\
\hline 9 & Zabierzów & Lesser Poland & krakowski & 25044 & 9942 & rural \\
\hline \multicolumn{4}{|c|}{ Prussian partition } & 153692 & 115899 & \\
\hline 1 & Bartniczka & Kuyavian-Pom. & brodnicki & 4714 & 8340 & rural \\
\hline 2 & Gniewkowo & Kuyavian-Pom. & inowrocławski & 14831 & 17972 & urban-rural \\
\hline 3 & Piła & Greater Poland & pilski & 74609 & 10268 & urban \\
\hline 4 & Rojewo & Kuyavian-Pom. & inowrocławski & 4755 & 11976 & rural \\
\hline 5 & Tamówka & Greater Poland & złotowski & 3105 & 13245 & rural \\
\hline 6 & Trzemeszno & Greater Poland & gnieźnieński & 14441 & 17530 & urban-rural \\
\hline 7 & Wągrowiec & Greater Poland & wągrowiecki & 37237 & 36568 & urban-rural \\
\hline \multicolumn{4}{|c|}{ Russian partition } & 587786 & 375592 & \\
\hline 1 & Bielsk Podlaski & podlaskie & bielski & 33406 & 45695 & urban-rural \\
\hline 2 & Dąbrowo Biał. & podlaskie & sokólski & 12155 & 26384 & urban-rural \\
\hline 3 & Działoszyn & Łódź & pajęczański & 12872 & 12092 & urban-rural \\
\hline 4 & Filipów & podlaskie & suwalski & 4504 & 15081 & rural \\
\hline 5 & Grajewo & podlaskie & grajewski & 28273 & 32716 & urban-rural \\
\hline 6 & Iwaniska & świętokrzyskie & opatowski & 6941 & 10489 & rural \\
\hline 7 & Jedlnia-Letnisko & Mazovian & radomski & 12411 & 6558 & rural \\
\hline 8 & Liw & Mazovian & węgrowski & 7616 & 16947 & rural \\
\hline 9 & Łęczna & Lublin & łęczyński & 24027 & 7514 & urban-rural \\
\hline 10 & Łomża & podlaskie & łomżyński & 73464 & 23962 & urban-rural \\
\hline 11 & Moszczenica & Łódź & piotrkowski & 12909 & 11149 & rural \\
\hline 12 & Nagłowice & świętokrzyskie & jędrzejowski & 5176 & 11729 & rural \\
\hline 13 & Nowy Dwór Maz. & Mazovian & nowodworski & 28287 & 2821 & urban \\
\hline 14 & Ostrowiec Święt. & świętokrzyskie & ostrowiecki & 72277 & 4643 & urban \\
\hline 15 & Ostrówek & Łódź & wieluński & 4563 & 10138 & rural \\
\hline 16 & Ożarów & świętokrzyskie & opatowski & 11080 & 18329 & urban-rural \\
\hline 17 & Raszyn & Mazovian & pruszkowski & 21344 & 4391 & rural \\
\hline 18 & Sandomierz & świętokrzyskie & sandomierski & 24552 & 2869 & urban \\
\hline 19 & Stare Miasto & Greater Poland & koniński & 11555 & 9784 & rural \\
\hline 20 & Suwałki & podlaskie & suwalski & 76609 & 33012 & urban-rural \\
\hline 21 & Szczebrzeszyn & Lublin & zamojski & 11868 & 12350 & urban-rural \\
\hline 22 & Tomaszów Maz. & Łódź & tomaszowski & 75665 & 19112 & urban-rural \\
\hline 23 & Wysokie & Lublin & lubelski & 4702 & 11390 & rural \\
\hline 24 & Zalesie & Lublin & bialski & 4440 & 14711 & rural \\
\hline 25 & Złoczew & Łódź & sieradzki & 7272 & 11726 & urban-rural \\
\hline \multicolumn{4}{|c|}{ Total - 41 municipalities } & 923951 & 561058 & \\
\hline
\end{tabular}


Table 2. Characteristics of the administrative status of municipalities and the age structure of the researched people

\begin{tabular}{|c|c|c|c|c|c|c|}
\hline & \multicolumn{6}{|c|}{ Partition } \\
\hline & \multicolumn{2}{|c|}{ Austrian } & \multicolumn{2}{|c|}{ Prussian } & \multicolumn{2}{|c|}{ Russian } \\
\hline & Number & $\%$ & Number & $\%$ & Number & $\%$ \\
\hline Municipalities - total & 9 & & 7 & & 25 & \\
\hline Small municipalities & 4 & 44.44 & 3 & 42.86 & 11 & 44.00 \\
\hline Medium municipalities & 4 & 44.44 & 3 & 42.86 & 10 & 40.00 \\
\hline Large municipalities & 1 & 11.12 & 1 & 14.28 & 4 & 16.00 \\
\hline Rural municipalities & 5 & 55.56 & 3 & 42.86 & 11 & 44.00 \\
\hline Urban-rural municipalities & 3 & 33.33 & 3 & 42.86 & 11 & 44.00 \\
\hline Urban municipalities & 1 & 11.11 & 1 & 14.28 & 3 & 12.00 \\
\hline Participants - total & 605 & & 555 & & 1874 & \\
\hline Males & 282 & 46.61 & 264 & 47.57 & 877 & 46.80 \\
\hline Females & 323 & 53.39 & 291 & 52.43 & 997 & 53.20 \\
\hline $\begin{array}{l}\text { Males -age (years) } \\
(\mathrm{X} \pm \mathrm{SD})\end{array}$ & \multicolumn{2}{|c|}{$45.55 \pm 16.0$} & \multicolumn{2}{|c|}{$45.84 \pm 15.96$} & \multicolumn{2}{|c|}{$46.22 \pm 15.16$} \\
\hline $\begin{array}{l}\text { Males- age (years) } \\
\text { Distribution }\end{array}$ & 282 & & 264 & & 877 & \\
\hline$<30$ & 61 & 21.63 & 60 & 22.73 & 149 & 16.99 \\
\hline $30-39$ & 48 & 17.02 & 37 & 14.02 & 163 & 18.59 \\
\hline $40-49$ & 44 & 15.60 & 49 & 18.56 & 197 & 22.46 \\
\hline $50-59$ & 66 & 23.40 & 55 & 20.83 & 168 & 19.1 \\
\hline$\geq 60$ & 63 & 22.34 & 63 & 23.86 & 200 & 22.81 \\
\hline $\begin{array}{l}\text { Females - age (years) } \\
(\mathrm{X} \pm \mathrm{SD})\end{array}$ & \multicolumn{2}{|c|}{$43.95 \pm 15.20$} & \multicolumn{2}{|c|}{$44.46 \pm 14.21$} & \multicolumn{2}{|c|}{$45.13 \pm 15.13$} \\
\hline $\begin{array}{l}\text { Females - age (years) } \\
\text { Distribution }\end{array}$ & 323 & & 291 & & 997 & \\
\hline$<30$ & 66 & 20.43 & 51 & 17.53 & 211 & 21.16 \\
\hline 30-39 & 67 & 20.74 & 65 & 22.34 & 160 & 16.05 \\
\hline 40-49 & 71 & 21.98 & 64 & 21.99 & 224 & 22.47 \\
\hline $50-59$ & 61 & 18.89 & 61 & 20.96 & 202 & 20.26 \\
\hline$\geq 60$ & 58 & 17.96 & 50 & 17.18 & 200 & 20.06 \\
\hline
\end{tabular}

Table 3 presents the results of the average consumption of 19 products in territories previously under annexed: Austrian, Prussian and Russian. It was shown that in these areas there are statistically significant differences in the consumption of pork, beef, butter, lard, pasta, light bread, buns, fresh vegetables, jams and sugar in both sexes. In women, there were also significant differences in the consumption of milk and in men there were sausages. The level of significance of differences in consumption of these products between individual partitions is presented in Table 4.
Milk consumption was significantly different only in women and it was the lowest in the area of former Prussian annexation in comparison to areas under other annexation. Pork consumption was significantly higher in the Russian partition than its consumption in the Austrian partition of both sexes. On the other hand, beef consumption was significantly lower in the area of the former Prussian partition compared to other partitions in men, and significantly lower in women than in the Russian partition, while in comparison with the Austrian partition it was lower on the borderline of statistical significance. The consumption of sausages was different only in men and was significantly higher among the residents of the former Russian annexation compared to Austrian. 


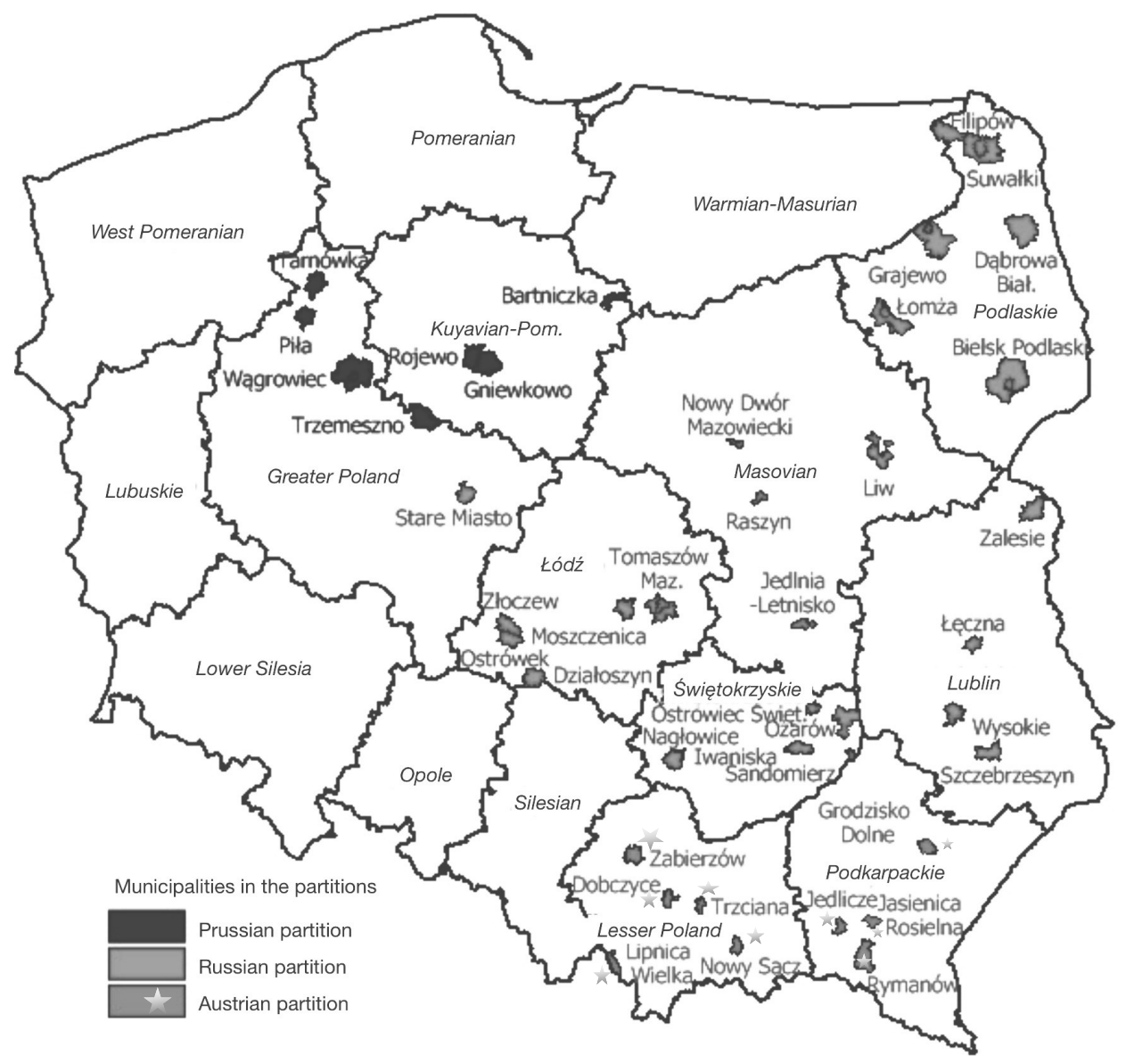

Figure 1. Distribution of municipalities included in the study

Table 3. Average values of consumption of products in areas previously under various annexations

\begin{tabular}{|c|c|c|c|c|c|c|c|c|}
\hline \multirow{3}{*}{ Product } & \multicolumn{3}{|c|}{ Partition } & \multirow{3}{*}{$\mathrm{p}$} & \multicolumn{3}{|c|}{ Partition } & \multirow{3}{*}{$\mathrm{p}$} \\
\hline & \multirow{2}{*}{$\begin{array}{c}\text { Austrian } \\
\mathrm{X} \pm \mathrm{SD}\end{array}$} & \multirow{2}{*}{$\begin{array}{c}\text { Prussian } \\
\mathrm{X} \pm \mathrm{SD}\end{array}$} & \multirow{2}{*}{$\begin{array}{c}\text { Russian } \\
\mathrm{X} \pm \mathrm{SD}\end{array}$} & & \multirow{2}{*}{$\frac{\text { Austrian }}{\mathrm{X} \pm \mathrm{SD}}$} & \multirow{2}{*}{$\frac{\text { Prussian }}{\mathrm{X} \pm \mathrm{SD}}$} & \multirow{2}{*}{$\begin{array}{c}\text { Russian } \\
\mathrm{X} \pm \mathrm{SD}\end{array}$} & \\
\hline & & & & & & & & \\
\hline \multicolumn{5}{|c|}{ Males } & \multicolumn{4}{|c|}{ Females } \\
\hline & $\mathrm{n}=282$ & $n=264$ & $\mathrm{n}=877$ & & $n=323$ & $\mathrm{n}=291$ & $\mathrm{n}=997$ & \\
\hline Milk (g) & $137.67 \pm 243.28$ & $88.74 \pm 174.00$ & $116.35 \pm 237.67$ & 0.1341 & $105.66 \pm 176.84$ & $74.69 \pm 146.00$ & $91.01 \pm 148.01$ & 0.0231 \\
\hline Pork (g) & $66.05 \pm 160.07$ & $77.05 \pm 142.79$ & $84.99 \pm 139.41$ & 0.0012 & $28.54 \pm 65.32$ & $35.06 \pm 65.14$ & $40.46 \pm 74.72$ & 0.0058 \\
\hline Beef (g) & $21.00 \pm 59.14$ & $7.31 \pm 30.24$ & $15.53 \pm 47.36$ & 0.0007 & $11.20 \pm 33.69$ & $6.66 \pm 23.61$ & $10.97 \pm 33.48$ & 0.0197 \\
\hline Sausages (g) & $66.55 \pm 93.19$ & $82.13 \pm 111.55$ & $74.03 \pm 86.97$ & 0.0313 & $28.79 \pm 52.92$ & $32.61 \pm 52.28$ & $26.66 \pm 40.68$ & 0.3826 \\
\hline Fish (g) & $4.73 \pm 30.94$ & $17.03 \pm 76.50$ & $7.83 \pm 41.87$ & 0.0586 & $5.18 \pm 31.41$ & $10.03 \pm 42.92$ & $9.01 \pm 42.51$ & 0.2475 \\
\hline Oils (g) & $10.76 \pm 21.14$ & $11.85 \pm 19.66$ & $11.29 \pm 16.66$ & 0.1395 & $7.54 \pm 12.24$ & $8.79 \pm 15.84$ & $9.42 \pm 15.45$ & 0.1207 \\
\hline Margarine (g) & $13.99 \pm 18.75$ & $22.81 \pm 33.77$ & $16.53 \pm 23.55$ & 0.1724 & $11.45 \pm 14.81$ & $12.76 \pm 18.50$ & $10.62 \pm 13.97$ & 0.7073 \\
\hline Butter (g) & $20.28 \pm 26.42$ & $19.79 \pm 31.93$ & $12.51 \pm 17.70$ & 0.0001 & $15.82 \pm 17.20$ & $14.28 \pm 18.46$ & $9.72 \pm 12.94$ & $<.0001$ \\
\hline Lard (g) & $10.99 \pm 21.59$ & $9.65 \pm 25.24$ & $8.58 \pm 16.76$ & 0.0316 & $7.08 \pm 15.63$ & $4.65 \pm 13.00$ & $6.66 \pm 15.41$ & 0.0487 \\
\hline Cereals (g) & $4.94 \pm 14.10$ & $4.23 \pm 15.34$ & $6.00 \pm 18.29$ & 0.1429 & $5.04 \pm 16.01$ & $4.20 \pm 16.69$ & $5.97 \pm 17.71$ & 0.0617 \\
\hline Pasta (g) & $11.92 \pm 21.81$ & $5.47 \pm 17.31$ & $10.16 \pm 27.58$ & $<.0001$ & $8.01 \pm 16.28$ & $5.72 \pm 14.93$ & $7.49 \pm 18.02$ & 0.0134 \\
\hline Light bread (g) & $170.90 \pm 129.57$ & $203.38 \pm 140.24$ & $166.86 \pm 141.54$ & $<.0001$ & $96.24 \pm 87.85$ & $98.80 \pm 76.24$ & $80.42 \pm 76.52$ & $<.0001$ \\
\hline Whole-grain bread (g) & $11.73 \pm 40.65$ & $16.34 \pm 61.27$ & $17.83 \pm 55.12$ & 0.1018 & $16.50 \pm 42.71$ & $14.90 \pm 43.94$ & $16.07 \pm 37.96$ & 0.3466 \\
\hline Rolls (g) & $34.12 \pm 65.21$ & $30.95 \pm 89.36$ & $37.62 \pm 67.83$ & 0.0018 & $21.84 \pm 37.27$ & $20.94 \pm 34.46$ & $29.28 \pm 45.49$ & 0.0111 \\
\hline Vegetables (g) & $234.06 \pm 186.64$ & $125.86 \pm 175.34$ & $193.94 \pm 187.32$ & $<.0001$ & $216.44 \pm 157.13$ & $123.74 \pm 112.82$ & $161.23 \pm 138.41$ & $<.0001$ \\
\hline Potatos (g) & $352.52 \pm 265.50$ & $354.26 \pm 325.88$ & $361.65 \pm 284.21$ & 0.6204 & $265.86 \pm 216.90$ & $258.31 \pm 255.13$ & $249.76 \pm 243.07$ & 0.2715 \\
\hline Fruits(g) & $177.40 \pm 226.27$ & $160.01 \pm 193.86$ & $195.78 \pm 261.90$ & 0.5043 & $239.14 \pm 272.88$ & $188.86 \pm 176.62$ & $222.11 \pm 231.50$ & 0.5366 \\
\hline Jams (g) & $1.97 \pm 9.26$ & $6.36 \pm 19.81$ & $5.70 \pm 20.52$ & 0.0011 & $3.18 \pm 14.39$ & $4.96 \pm 14.84$ & $6.25 \pm 19.00$ & 0.0007 \\
\hline Sugar (g) & $46.47 \pm 37.69$ & $38.78 \pm 34.66$ & $39.72 \pm 34.67$ & 0.0110 & $38.30 \pm 31.68$ & $29.39 \pm 28.49$ & $29.51 \pm 27.79$ & $<.0001$ \\
\hline
\end{tabular}

$\mathrm{X}$ - mean, SD - standard deviation, $\mathrm{p}$ - $\mathrm{p}$ value ANOVA 
Consumption of butter was indeed the highest in the Austrian Partition, both in comparison with the Russian and Prussian annexations, in both sexes, and in the lard only in men. The consumption of lard in women was significantly higher in the Austrian partition compared to Prussian and Russian compared to Prussian.

Consumption of pasta was significantly lower in the area of former Prussian annexation in comparison to other partitions in both sexes, and in men it was significantly higher in Austrian than in Russian. Consumption of light bread was significantly higher among the residents of the former Partitions of Prussian as compared to the other partitions in men, while in women only compared to Russian. In addition, women were significantly higher in the Austrian partition than Russian. Consumption of rolls was significantly higher in men in the former Russian and Austrian annexation than in Prussian, and in women significantly higher in Russian than in other partitions.

Significantly significant statistical differences related to the consumption of vegetables, which in both sexes was significantly highest in the former Austrian Partition, and the lowest in Prussia. In both sexes consumption of jams was significantly lower, and sugar significantly higher in the area of the former Austrian annexation in comparison with other partitions.

Table 4. P-values for differences in consumption of products between individual partitions

\begin{tabular}{|c|c|c|c|c|c|c|}
\hline \multirow[b]{2}{*}{ Product } & \multicolumn{6}{|c|}{$\mathrm{p}$-value for differences between partitions } \\
\hline & $\begin{array}{l}\text { Austrian - } \\
\text { Prussian }\end{array}$ & $\begin{array}{c}\text { Austrian - } \\
\text { Russian }\end{array}$ & $\begin{array}{l}\text { Prussian - } \\
\text { Russian }\end{array}$ & $\begin{array}{c}\text { Austrian - } \\
\text { Prussian }\end{array}$ & $\begin{array}{c}\text { Austrian - } \\
\text { Russian }\end{array}$ & $\begin{array}{c}\text { Prussian - } \\
\text { Russian }\end{array}$ \\
\hline & \multicolumn{3}{|c|}{ Males } & \multicolumn{3}{|c|}{ Females } \\
\hline Pork & 0.1979 & 0.0005 & 0.0647 & 0.2006 & 0.0017 & 0.1592 \\
\hline Beef & 0.0004 & 0.5174 & 0.0004 & 0.0538 & 0.5400 & 0.0050 \\
\hline Sausages & 0.1089 & 0.0080 & 0.5893 & - & - & - \\
\hline Butter & 0.0242 & $<.0001$ & 0.3018 & 0.0223 & $<.0001$ & 0.0049 \\
\hline Lard & 0.0166 & 0.0216 & 0.5305 & 0.0180 & 0.4504 & 0.0367 \\
\hline Pasta & $<.0001$ & 0.0191 & 0.0003 & 0.0035 & 0.1959 & 0.0223 \\
\hline Light bread & 0.0029 & 0.2446 & $<.0001$ & 0.2386 & 0.0061 & $<.0001$ \\
\hline Rolls & 0.0052 & 0.7578 & 0.0005 & 0.9136 & 0.0150 & 0.0237 \\
\hline Vegetables & $<.0001$ & 0.0004 & $<.0001$ & $<.0001$ & $<.0001$ & $<.0001$ \\
\hline Jams & 0.0002 & 0.0020 & 0.1895 & 0.0041 & 0.0002 & 0.6405 \\
\hline Sugar & 0.0088 & 0.0059 & 0.5967 & 0.0001 & $<.0001$ & 0.6273 \\
\hline
\end{tabular}

\section{DISCUSSION}

The results of the analysis showed that inhabitants of areas that were in the past under various annexations, after 85 years after Poland regained independence, there were still significant differences in the way of feeding.

The areas of the former Austrian Partition, in comparison with the rest of the country, were characterized by the highest consumption of fresh vegetables, and also relatively large butter and lard. At the same time, pork consumption was relatively low in this area. In addition, this area, in comparison with the others, was characterized by low consumption of jams and high sugar. Thus, it can be assumed that the cuisine of the native inhabitants of the former Austrian Partition was still to a certain extent determined by the dietary habits typical of the Austrian Partition, which were similar to the typically German customs, but were definitely "lighter", which was influenced by the culinary traditions of southern ethnic groups. under the Habsburgs [23, 25]. Most of the culinary traditions of the Habsburg Empire were taken over by Galicja, located mostly in the northern Podkarpacie, in the Beskids and the Carpathians. In the Galician cuisine vegetables such as peppers and aubergines were available, which in other parts of the Polish partitions were not popular and used in the preparation of dishes $[2,12,31]$.

The nutrition model of the inhabitants of the former Prussian Partition was characterized by a small consumption of fresh vegetables, pasta and beef, while a large light bread $[10,15]$. The consumption of milk in this area was relatively low, which concerned mainly women. It can therefore be said that the way of feeding the local population retained some characteristics of typical German cuisine, in which the share of vegetables and pasta is small, and among meat dishes made of beef have a small share. It is also worth emphasizing that traditionally less-than-equal-sized bread is preferred $[5,7]$. 
For the area of the former Russian partition, the most characteristic was relatively high consumption of pork, and in men also sausages, at least compared to the former Austrian partition, as well as bread rolls. In addition, the consumption of fresh vegetables was quite high, at least compared to the area of the former Prussian partition. The intake of jams was also quite large, at least in comparison with the areas of the former Austrian Partition. This may be to a certain extent determined by the traditions of Russian cuisine $[3,6,16,29]$.

Poland is a country that combines many food traditions, because at the turn of the centuries many cultures and nationalities permeated the territory of the Polish state [21]. Everything depends on how long the given nations remained in Poland and which regions they covered [1]. Over a century of annexation changed the feeding habits of people from areas occupied by the occupiers. In particular areas, the consumption of products important for Prussian, German or Russian cuisine can be perceived [4].

Therefore, it can be assumed that the history of the region and the related penetration of different nations in one common country have an undoubted influence on the way of feeding a given region. It is a natural stage in the process of the country's evolution. It can be noticed that the areas of former partitions took over culinary customs of the partitioning countries. For many centuries, Poles' dietary preferences shaped on the background of historical events (royal weddings, geographical discoveries, thanks to which new products appeared) [9].

Analyzing the results of our study, however, it can not be said that the increased consumption of products typical of the partitioning countries depends only on the presence of another nation in that territory. Human nutritional preferences are shaped by many factors: personal, socioeconomic, educational, biological, psychological, physiological, cultural, religious, regional and historical $[19,24]$. It is worth noting that the results of the study indicate that part of the differences in consumption concerns women and some men. Thus, other than the possible historical reasons for observed differences should also be taken into account.

It can be assumed that apart from the cultural influence of the partitioners and their eating habits in the areas occupied by them on the level of consumption of certain products by Poles, the reasons for such diversity can also be found in the individual characteristics of a given community, the norms of behavior in it, or individual differences between individuals and in their psychological features. Relations with other people, often distant cultures, nations and their customs should also be taken into account $[27,30]$.
Summarizing, it should be said that after 85 years since Poland regained its independence and reunification of the country, there were still differences in the way of feeding the indigenous inhabitants of the areas under Austrian, Prussian and Russian annexation.

\section{CONCLUSIONS}

1. The way of feeding indigenous people living in areas that were once partitions of Poland is still diverse and similar to the cuisine of the occupying country.

2. In the area of indigenous peoples who were in the past under different annexations, after 85 years after Poland regained its independence, there were still differences in the way of nutrition.

3. The way of feeding in the areas of the former Partitions of Prussia, Austria and Russia seems to be still to some extent determined by the dietary habits typical of the countries to which these areas were subject in the past.

\section{Conflict of interest}

The authors declare no conflict of interest.

\section{REFERENCES}

1. Babicz-Zielińska E.: Studia nad preferencjami pokarmowymi oraz determinantami wyboru żywności w wybranych grupach konsumenckich. Prace Naukowe Wyższej Szkoły Morskiej, Gdynia, 1999.

2. Barnaś-Baran E.: Świętowanie w wiejskiej rodzinie galicyjskiej. Studia i prace pedagogiczne 2014 (1) Rozprawy i materiały, 2014: 173-288.

3. Bołdyrew A.: Poradniki i czasopisma jako źródło postulatywne do badań nad pożywieniem dzieci i młodzieży na ziemiach Królestwa Polskiego w latach 1795-1914 (Perspektywa społeczno-kulturowa i zdrowotno- wychowawcza). Studia z historii społeczno- gospodarczej, 2013, XI

4. Byszewska I.: Nasze kulinarne dziedzictwo. Za miastem 2005.

5. Chawla M.: Smaki i zapachy kuchni świata. Conference: Tajemnice smaku produktów regionalnych i tradycyjnych, Kraków 19-22.06.2006.

6. Domine A., Romer J.: Culinaria Kuchnie Europy. Konneman, Koln, 2001

7. Dudek H.: Struktura spożycia mięsa w Polsce i w krajach Unii Europejskiej. Wybrane problemy nauki o żywieniu człowieka u progu XXI wieku, Warszawa, 2004.

8. Eberhardt $P .:$ Migracje polityczne na ziemiach polskich (1939-1950). Instytut Zachodni, Poznań 2010.

9. Higman B.W.: Historia żywności. Jak żywność zmieniła świat, Wydawnictwo Aletheia, Warszawa, 2012.

10. Kazimierczak R.: Spożycie warzyw i owoców w Polsce w latach 1993-2002. Wybrane problemy nauki o żywieniu człowieka u progu XXI wieku, (red.) K. Gutkowska, A. Brzozowska. SGGW, Warszawa 2004: 220-225. 
11. Kowalczyk A., Gwiazdowska K.: Zmiany upodobań żywieniowych i zainteresowanie kuchniami etnicznymi - przyczynek do turystyki (kulinarnej)?. Turystyka Kulturowa, 9/2015.

12. Lesisz M.: Kuchnia Austriaków. NIWA Rolnicza, Nowości, Informacje, Wiadomości, Agrobiznes, 1997: 2930.

13. Łebkowski M.: Kuchnia Polska. Dania na każdą okazję. Reader's Digest, 2000.

14. Łozińska M., Łoziński J.: Historia polskiego smaku. Kuchnia. Stół. Obyczaje, PWN, 2012

15. Łukasiewicz D.: Choroba i zdrowie w Królestwie Prus w XIX wieku. Colloquium Wydziału Nauk Humanistycznych i Społecznych, 2/2013: 7-36.

16. Łukasik I., Sado A.: Kuchnia rosyjska. Wydawnictwo REA, Warszawa, 2009

17. Maison D.: Motywy i bariery zmiany postaw i zachowań żywieniowych. Żywienie Człowieka i Metabolizm, 2013, XI (3): 192-212.

18. Meyzie P.: Kuchnia w Europie doby nowożytnej. Jeść i pić: XVI-XIX wiek, Oficyna Wydawnicza Mówią Wieki, Warszawa, 2012.

19. Narojek L.: Niektóre aspekty uwarunkowań zachowań żywieniowych. Instytut Żywności i Żywienia, Warszawa, 1993.

20. Nakwaska K.: Dwór wiejski, dzieło poświęcone gospodyniom polskim, przydatne i osobom w mieście mieszkającym, I-III, Poznań 1843-1844

21. Ogrodowska B.: Polskie obrzędy i zwyczaje doroczne. Ocalić od zapomnienia, Wyd. Sport i Turystyka, Muza SA, Warszawa 2005.

22. Olczak E.: Atlas historii Polski. Mapy i komentarze. Demart, 2006.
23. Praschl-Bichler G.: Prywatne życie cesarza Franciszka Józefa. Wydawnictwo Bellona, Warszawa, 1994.

24. Pilska M., Jeżewska-Zychowicz M.: Psychologia żywienia. Wybrane zagadnienia, Wydawnictwo SGGW, Warszawa, 2008.

25. Rataj A.: Zwyczaje żywieniowe i sztuka kulinarna a dziedzictwo kulturowe narodów. Conference: Tajemnice smaku produktów regionalnych i tradycyjnych, Kraków 19-22.06.2006

26. Rywik S., Kupść W., Piotrowski W., et al.: Wieloośrodkowe ogólnopolskie badanie stanu zdrowia ludności-projekt WOBASZ. Założenia metodyczne oraz logistyka, Kardiologia Polska 2005; 63 : 6 (4): 1-9.

27. Sieczko A.: Edukacyjny charakter polskich kuchni regionalnych. Wydział Ekonomiczno-Rolniczy SGGW, Warszawa 2007.

28. Śniadecki J., Leśniewski P.E.: Poradnik dla gospodyń wiejskich i miejskich, czyli zbiór rad, wiadomości i przepisów obejmujący różne szczegóły gospodarstwa kobiecego. III, Warszawa 1838.

29. Wilmowska I., Głowacki M.: Wybory i postawy żywieniowe konsumentów. Żywienie Człowieka i Metabolizm, 2013, XI (3): 213-225.

30. Żarnowska A.: Między kulturą ludową a drobnomieszczańską. Narodziny kultury robotniczej na ziemiach polskich na przełomie XIX i XX wieku. „Kwartalnik Historyczny", vol. XCII, Wrocław 1985.

31. Żyromski M.: Nawyki żywieniowe w dziejach rodziny polskiej. Blaski i cienie życia rodzinnego. Roczniki socjologii rodziny XV, UAM, Poznań 2003:95-112.

Received: 21.05 .2019

Accepted: 29.08.2019

This article is available in Open Access model and licensed under a Creative Commons Attribution-Non Commercial 3.0.Poland License (CC-BY-NC) available at: http://creativecommons.org/licenses/by-nc/3.0/pl/deed.en 